\title{
PENINGKATAN KETERAMPILAN PROSES, MOTIVASI, DAN HASIL BELAJAR BIOLOGI DENGAN STRATEGI PEMBELAJARAN INKUIRI TERBIMBING PADA SISWA KELAS VII SMP KARTIKA V-1 BALIKPAPAN
}

\author{
Euis Yuniastuti \\ Dosen Fakultas Keguruan dan Ilmu Kependidikan \\ Universitas Tridharma Balikpapan \\ email: euis_yuniast@gmail.com
}

\begin{abstract}
ABSTRAK
Penelitian ini dirancang sebagai sebuah Penelitian Tindakan Kelas (Classroom Action Research) dengan tiga siklus pembelajaran yang dilaksanakan SMP Kartika V-1 Balikpapan dan bertujuan meningkatkan keterampilan proses sains, motivasi belajar, dan hasil belajar biologi siswa kelas VII melalui strategi pembelajaran inkuiri terbimbing. Selama penelitian berlangsung, peneliti bertindak sebagai guru kelas, dan selama kegiatan pengamatan, peneliti dibantu oleh rekan-rekan sejawat. Pengumpulan data lapangan dilakukan melalui pengisian lembar observasi, wawancara, pembuatan catatan lapangan, pengambilan dokumentasi, dan pengadaan tes. Analisis data secara kualitatif dilakukan untuk menjelaskan motivasi dan keterampilan proses siswa sedangkan analisis kuantifatif diperlukan untuk menjelaskan peningkatan hasil belajar siswa. Hasil penelitian menunjukkan bahwa terjadi peningkatan keterampilan proses (rata-rata keterlaksanaan 55\% pada siklus I, 69,38\% pada siklus II, dan 80,63\% pada siklus III), motivasi belajar siswa (rata-rata keterlaksanaan 60,74\% pada siklus I, 69,63\% pada siklus II, dan $80,00 \%$ pada siklus III) dan hasil belajar siswa (rata - rata persentase ketuntasan sebesar 45,56\% pada siklus I, $58,89 \%$ pada siklus II, dan $86,67 \%$ pada siklus III). Berdasarkan analisis hasil penelitian, dapat disimpulkan bahwa pembelajaran dengan strategi inkuiri terbimbing mampu meningkatkan motivasi belajar dan keterampilan proses siswa yang secara konsekutif berdampak pada kenaikan ketuntasan belajar siswa.
\end{abstract}

Kata kunci: keterampilan proses, motivasi belajar, hasil belajar, inkuiri terbimbing

\section{ABSTRACT}

This research was designed as a classroom action with three-cycle learning process research which took place in SMP Kartika V-1 Balikpapan and purposes on improving process skills, learning motivation, and learning outcomes in Biology subject of seventh grade students through guided inquiry strategy. Throughout the research, the researcher had a role as the teacher, whilst the researcher's acquaintances handled the observation activity. All research data obtainment was carried out by completing observation forms, interviewing students, arranging field notes, taking documentations, and conducting tests. Qualitative analysis was conducted to explicate the students' learning motivation and process skills profile, whilst quantitative analysis was also conducted to explain the improvement of students'learning outcomes. The results show the significant improvement in students 'process skills (55.00\% average accomplishment on cycle I, $69.38 \%$ on cycle II, and $80.00 \%$ on cycle III), learning motivation (60.74\% average accomplishment on cycle I, $69.63 \%$ on cycle II, and $80.00 \%$ on cycle III), and learning outcomes (45.56\% average learning accomplishment on cycle I, $58.89 \%$ on cycle II, and $86.67 \%$ on cycle III) on each cycle. Based on the research analysis, it can be concluded that implementing guided inquiry is a viable strategy to improve students'learning motivation and process skills, which consecutively impacts the improvement of students learning accomplishments.

Keywords: process skills, learning motivation, learning outcomes, guided inquiry

\section{PENDAHULUAN}

Pada dasarnya pendidikan menuntut keaktifan dari peserta didik, khususnya pembelajaran sains yang berhubungan dengan pengalaman dan kehidupan sehari-hari yang pernah dialami peserta didik. Akan tetapi pada kenyataannya pembelajaran sains, khususnya mata pelajaran Biologi, masih didominasi oleh penggunaan metode ceramah. Peserta didik hanya mendengarkan penjelasan guru dan mencatat hal-hal yang dianggap penting.
Proses pembelajaran siswa dilaksanakan secara pasif (Nuryani, 2005).

Pada hakikatnya, biologi sebenarnya merupakan pendidikan berorientasi kehidupan, serta lingkungan dan pelaksanaannya sangat dipengaruhi oleh lingkungan masyarakat. Rasanya tidak sesuai jika pembelajaran biologi hanya dilakukan di ruang kelas tanpa adanya kegiatan lapangan. Dengan demikian, guru biologi sangat perlu menguasai materi biologi secara lebih 
mendalam dengan strategi serta keterampilan mengajar yang baik.

Selain itu, biologi masih diajarkan dengan sistem hafalan sehingga kurang mengembangkan proses berpikir. Seharusnya, pembelajaran biologi yang baik ialah pembelajaran yang dilandaskan pada prinsip keterampilan proses, di mana siswa dididik untuk menemukan dan mengembangkan sendiri fakta dan konsepnya sendiri.

Penerapan keterampilan proses dalam pembelajaran biologi dapat diintegrasi di dalam kegiatan praktikum siswa, akan tetapi dibutuhkan strategi pembelajaran khusus agar keterampilan proses siswa terus berkembang, salah satunya ialah strategi pembelajaran inkuiri terbimbing. Melalui strategi ini, siswa tetap didorong untuk secara aktif menyusun eksperimen hingga menyimpulkan hasilnya namun tetap diberikan arahan/bimbingan dari guru.

Melalui pembelajaran ini, siswa diharapkan memiliki kemampuan menguasai konsep, meningkatkan kreativitas, dan kesadaran dalam memahami permasalahan yang berkaitan dengan pelestarian lingkungan. Keterlibatan siswa secara aktif dalam strategi pembelajaran ini dapat membantu mereka memecahkan permasalahan nyata dan merespon secara aktif terhadap fenomena alam di sekitar mereka

Berdasarkan pengamatan/analisis lapangan, permasalahan yang dapat diidentifikasi antara lain: (1) Proses pembelajaran masih berpusat pada guru; (2) Siswa kurang aktif dan kurang terlibat dalam proses pembelajaran; (3) Siswa kurang mampu memecahkan serta menyikapi permasalahan yang dihadapinya; (4) Pembelajaran lebih mementingkan segi hafalan; (5) Siswa kurang mampu mengaplikasikan pengetahuannya dalam kehidupan nyata; (6) Guru kurang siap dalam perencanaan pembelajaran; dan (7) Pembelajaran kurang bermakna.

Ruang lingkup penelitian ini antara lain:
(1) Keterampilan proses siswa yang diukur ada delapan; (2) aspek yakni mengajukan hipotesis, menggunakan alat/bahan, melaksanakan percobaan, mengamati, menggolongkan, melakukan komunikasi, menafsirkan informasi, dan menerapkan konsep; (3) Motivasi belajar siswa yang diukur ada lima belas aspek yakni perhatian dengan pelajaran, rasa ingin tahu, paham tujuan pembelajaran, dapat bekerja sama, bertukar pendapat, berani mencoba hal baru, berani bertanya, fokus pada tugas, mencoba berbuat lebih baik, berpendapat, keaktifan mencari sumber belajar lain, berlomba menyelesaikan tugas, mencari ide baru solusi, mampu berdiskusi, dan bekerja keras dalam penyelesaian tugas; (4) Hasil belajar dibatasi pada ranah kognitif dan diukur melalui pretest, tes formatif 1 dan 2, tes akhir siklus, dan post-test; (5) Materi pembelajaran dibatasi pada materi Pencemaran Lingkungan; dan (6) Subjek dalam penelitian ialah siswa kelas VII SMP Kartika V-1 Balikpapan sejumlah 30 orang

Rumusan masalah: (1) Bagaimana peningkatan keterampilan proses sains siswa kelas VII SMP Kartika V-1 Balikpapan dengan strategi pembelajaran Inkuiri Terbimbing?; (2) Bagaimana peningkatkan motivasi belajar biologi siswa kelas VII SMP Kartika V-1 Balikpapan dengan strategi pembelajaran Inkuiri Terbimbing?; dan (3) Bagaimana peningkatkan hasil belajar biologi siswa kelas VII SMP Kartika V-1 Balikpapan dengan strategi pembelajaran Inkuiri Terbimbing?

Tujuan penelitian ingin meningkatkan keterampilan proses sains, motivasi belajar, dan hasil belajar biologi siswa kelas VII SMP Kartika V-1 Balikpapan

Bagi siswa, penelitian ini diharapkan dapat berguna dalam: meningkatkan motivasi belajar biologi, keterampilan proses sains, hasil belajar biologi, dan mengembangkan sikap ilmiah. Bagi guru, penelitian 
ini diharapkan dapat berguna dalam meningkatkan keterampilan guru untuk menyusun konsep biologi, wawasan dan profesi guru, rujukan dalam pengembangan keterampilan proses siswa, dan rujukan dalam penentuan strategi pembelajaran yang sesuai. Bagi peneliti lain, penelitian ini diharapkan dapat memberi masukan dan bahan pertimbangan untuk penelitian sejenis pada konsep biologi lain.

Kajian pustaka dalam penulisan ini adalah:

\section{A. Pembelajaran Biologi di Tingkat SMP}

Menurut Dimyati (2002:7), Belajar merupakan tindakan dan perilaku siswa yang kompleks. Siswa adalah penentu terjadinya proses belajar, yang terjadi karena siswa mempelajari sesuatu yang ada di lingkungan sekitar berupa keadaan alam, benda-benda, hewan, tumbuhan, manusia, atau hal - hal lain yang dijadikan bahan belajar.

Siswa yang belajar sains, menurut Susanto (2003:6) tidak lagi menerima informasi tentang produk sains, tetapi melakukan proses ilmiah untuk menemukan fakta dan membangun konsep dan prinsip di bidang sains. Khususnya untuk pembelajaran biologi pada tingkat SMP, pemberian pengalaman secara langsung perlu ditingkatkan dengan demikian siswa mampu menerapkan teori yang telah dipelajari dalam biologi bagi kehidupan mereka sehari-hari. Oleh karena itu siswa perlu dibantu untuk mengembangkan sejumlah keterampilan proses agar mereka mampu mengeksplorasi dan memahami fenomena alam sekitar (Asmani, 2009).

\section{B. Strategi Pembelajaran Inkuiri Terbimbing}

Inkuiri berasal dari bahasa Inggris inquiry yang berarti "proses bertanya dan mencari tahu jawaban terhadap pertanyaan ilmiah yang diajukan". Lebih lanjut, Depdikbud dalam Ibrahim (2007) mengemukakan bahwa inkuiri ialah proses yang bervariasi dan meliputi kegiatan-kegiatan observasi, merumuskan pertanyaan yang relevan, mengevaluasi buku dan sumber-sumber informasi lain secara kritis, merencanakan penyelidikan/investigasi, mengulas apa yang telah diketahui, melaksanakan percobaan atau eksperimen dengan menggunakan alat untuk memperoleh data, menganalisis dan menginterpretasi data, serta membuat prediksi dan mengkomunikasikan hasilnya.

Dua pendekatan inkuiri yang diketahui antara lain inkuiri terbimbing dan inkuiri bebas. Pada inkuiri terbimbing, siswa dihadapkan pada tugas yang relevan untuk diselesaikan baik melalui diskusi kelompok maupun individual agar mampu menyelesaikan masalah dan menarik kesimpulan secara mandiri, akan tetapi siswa tetap memperoleh pedoman/bimbingan berupa pertanyaan atau diskusi serta pemantauan dari guru.

Berbeda halnya dengan inkuiri terbimbing, pembelajaran inkuiri bebas menempatkan siswa seolah-olah sebagai ilmuwan sehingga diberikan kebebasan menentukan permasalahan yang akan diselidiki, merancang prosedur eksperimen secara mandiri, dan siswa diberikan sedikit/tidak sama sekali bimbingan dari guru. Akan tetapi inkuiri bebas memiliki kelemahan di antaranya waktu yang relatif lama sehingga bisa melebihi alokasi waktu dalam kurikulum dan pemilihan topik permasalahan kelompok yang bisa melenceng dari konteks materi pembelajaran.

\section{Keterampilan Proses Sains}

Menurut Semiawan (1992:12), keterampilan proses ialah keterampilan fisik dan mental terkait dengan kemampuan- kemampuan yang mendasar yang dimiliki, dikuasai, dan diaplikasikan dalam suatu kegiatan ilmiah, sehingga para ilmuan berhasil menemukan sesuatu yang baru. Rangkaian keterampilan proses menurut Rustaman et.al (2003:191) antara lain mengamati, menggolongkan, menafsirkan, meramalkan, menerapkan, merencanakan penelitian, dan mengkomunikasikan.

Pelaksanaan penilaian keterampilan proses siswa bisa berupa tes dan non-tes. Penilaian berupa tes dilakukan dengan 
membuat pertanyaan dalam bentuk esai (sisi subjektivitas/individualisme siswa) atau pilihan ganda (objektivitas siswa). Akan tetapi penilaian berupa tes seringkali hanya memberi peluang tebakan sehingga berbeda dari kondisi siswa sesungguhnya. Penilaian berupa non-tes menurut Sumiati dan Asra (2008), Arikunto (2009), dan Widyaningtyas (2010), membutuhkan sebuah lembar pengamatan yang dapat berisi rubrik, daftar cek, atau skala bertingkat. Penilaian kemampuan siswa didasarkan pada jenisjenis kriteria yang telah ditetapkan, yakni pemberian level unjuk kerja secara kuantatif dengan angka 1, 2, 3, dan 4 dan secara kualitatif sebagai interpretasinya.

\section{Motivasi Belajar Siswa}

Menurut Djamarah (2002:114), motivasi ialah suatu pendorong yang mengubah energi dalam diri seseorang ke dalam bentuk aktivitas nyata untuk mencapai tujuan tertentu.

Pada dasarnya, motivasi belajar siswa dibedakan menjadi dua jenis, yakni motivasi intrinsik dan motivasi ekstrinsik. Menurut Usman (2010:29), motivasi ini timbul sebagai akibat dari dalam individu tersebut karena adanya ajakan, suruhan, atau paksaan dari orang lain sehingga dengan kondisi yang demikian akhirnya ia mau melakukan sesuatu atau belajar. Motivasi ekstrinsik menurut Djamarah (2002:117) ialah motifmotif yang aktif dan berfungsi karena adanya rangsangan dari luar, seperti adanya kompetisi/persaingan.

\section{E. Penelitian Tindakan Kelas}

Menurut Arikunto (2009), Penelitian Tindakan Kelas (PTK) merupakan gabungan definisi dari tiga kata, "penelitian, tindakan, dan kelas". Penelitian merupakan kegiatan mencermati suatu objek dengan menggunakan aturan metodologi ilmiah untuk memperoleh data/informasi yang bermanfaat bagi peneliti atau orang-orang yang berkepentingan. Tindakan ialah suatu gerak kegiatan dalam bentuk rangkaian periode/siklus yang sengaja dilakukan dengan tujuan memperbaiki mutu proses belajar mengajar. Kelas ialah sekelompok siswa yang dalam waktu dan tempat yang sama menerima pelajaran yang sama dari seorang guru yang sama.

Karakteristik dari PTK antara lain: (1) Penelitian berawal dari masalah guru atas kinerjanya; (2) Fokus penelitian berupa kegiatan pembelajaran; (3) Bersifat siklussiklus yang terdiri dari perencanaan, pemberian tindakan, pengamatan, dan refleksi; (4) Berlangsung dalam jangka waktu tertentu secara teratur; dan (5) Pelaksanaannya secara kolaboratif karena melibatkan pihak lain, misalnya observer

Menurut Aqib (2009:6), manfaat PTK bagi guru antara lain untuk memperbaiki pembelajaran, profesionalisme, dan kepercayaan diri guru. PTK juga membantu sekolah untuk berkembang sebagai konsekuensi adanya kemajuan pada diri guru dan pendidikan di sekolah tersebut.

\section{F. Penelitian Relevan}

Beberapa hasil penelitian yang relevan terhadap penelitian yang dilakukan penulis antara lain: (1) Penelitian oleh Elsye Theodora Maasawet yang berjudul "Meningkatkan Kemampuan Kerja Sama Belajar Biologi Melalui Penerapan Strategi Inkuiri Terbimbing pada Siswa Kelas VII SMP Negeri VI Kota Samarinda Tahun Pelajaran 2010/2011" memaparkan hasil bahwa melalui penerapan strategi inkuiri terbimbing terjadi peningkatan kemampuan kerja sama siswa dalam belajar biologi pada siklus I adalah 12,04\% meningkat menjadi $61,58 \%$ pada siklus kedua, dan meningkat lagi pada siklus ketiga $84,53 \%$; dan (2) Waryanto dalam penelitiannya yang berjudul "Peningkatan Keterampilan Proses Sains dan Partisipasi Siswa pada Pembelajaran Biologi Melalui Penerapan Inkuiri Terbimbing di Kelas X-1 SMA Negeri I Sukoharjo Tahun Pelajaran 2011/2012", menunjukkan bahwa 
terjadi peningkatan persentase keterampilan proses pada siklus I sebesar $63 \%$ dan pada siklus II meningkat $81 \%$. Sedangkan partisipasi siswa siklus I adalah $61 \%$ terjadi peningkatan pada siklus II menjadi $77 \%$.

\section{METODE PENELITIAN}

Penelitian yang dilakukan merupakan Penelitian Tindakan Kelas (PTK) yang ditujukan untuk melakukan perbaikan dan peningkatan layanan profesional guru. Subjek penelitian ialah siswa kelas VII-1 SMP Kartika V-1 Balikpapan Tahun Pelajaran 2011/2012 yang berjumlah 30 siswa. Penelitian dilakukan dari bulan Mei sampai bulan Juni tahun 2012 dan berlokasi di SMP Kartika V-1 Balikpapan, Provinsi Kalimantan Timur. Dalam penelitian, peran dan posisi peneliti ialah sebagai pengelola instrumen, perancang tindakan, dan pengumpul data. Pada proses pelaksanaan, peneliti dibantu rekan sejawat sebagai observer.

Penelitian ini terdiri dari tiga siklus pertemuan yang masing-masing terdiri dari empat tahap: merencanakan, melakukan tindakan, mengamati, dan merefleksi. Materi pembelajaran pada siklus 1 ialah pencemaran udara, pada siklus 2 ialah pencemaran tanah, dan pada siklus 3 ialah pencemaran air. Setiap siklus terdiri dari tiga pertemuan dan diakhir tiap pertemuan dilakukan evaluasi berupa tes formatif 1 (setelah pertemuan 1), tes formatif 2 (setelah pertemuan 2), dan tes akhir siklus (setelah pertemuan 3). Sebelum siklus 1 dimulai, kelas diberikan pre-test dan setelah siklus 3 berakhir, kelas diberikan post-test untuk evaluasi seluruh materi.

Beberapa instrumen penelitian yang digunakan antara lain lembar observasi guru, lembar observasi siswa, catatan lapangan, dan dokumentasi. Pengujian keabsahan data dilakukan dengan empat uji yakni uji kredibilitas (triangulasi dan diskusi dengan rekan sejawat), uji ketersampaian (validitas eksternal agar dapat dipahami oleh peneliti lain), uji dependabilitas (audit untuk menyeseuaikan dengan prosedur), dan uji konformabilitas (uji objektivitas penelitian).

Analisis data secara kualitatif dilakukan dengan memanfaatkan data kualitatif berupa hasil observasi, catatan lapangan, dan wawancara untuk membandingkan proses pembelajaran dari siklus I hingga siklus III. Penilaian keterampilan proses siswa dilakukan secara semi-kualitatif dengan menggunakan skor 1 sampai 4 dengan indikasi "kurang", "cukup", "baik", dan "sangat baik", sedangkan penilaian motivasi dilakukan secara semi-kualitatif pula dengan menggunakan skor 1 sampai 3 dengan indikasi "tidak dilakukan", "dilakukan", dan "sering dilakukan".

Analisis data secara kuantitatif dilakukan dengan membandingkan hasil tes formatif 1 , tes formatif 2, dan tes akhir pada setiap siklus, ditambah hasil pre-test sebelum siklus I dan post-test setelah siklus III. Nilai tes siswa memiliki kriteria ketuntasan minimal sebesar 65 untuk mengukur persentase ketuntasan belajar siswa tiap siklus.

\section{HASIL PENELITIAN}

Rekapitulasi secara umum hasil penelitian dapat dilihat dalam Gambar 1.

\section{A. Peningkatan Aktivitas Guru}

Aktivitas guru terlihat mengalami peningkatan dari siklus I sebesar $74,75 \%$, pada siklus II menjadi $89,90 \%$ dan pada siklus III mencapai 93,94\%. Pada siklus I, guru masih belum siap dan terlalu cepat menjelaskan kompetensi dasar sehingga siswa belum siap menggabungkan pemahaman terhadap materi sebelumnya yang telah disampaikan. Kondisi ini berkaitan dengan masalah kesiapan (readiness) siswa dalam menerima pembelajaran di awal. Hal ini sesuai dengan teori belajar asosiasi menurut Thorndike (Slameto, 2010:114) yang menyatakan kesiapan ialah prasyarat untuk belajar berikutnya. 


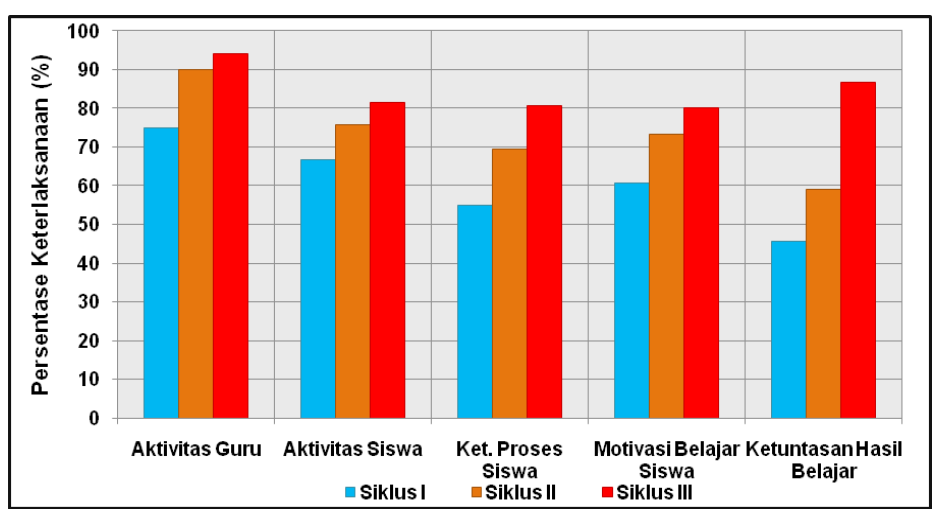

Gambar 1

Diagram rekapitulasi keseluruhan hasil pembelajaran inkuiri terbimbing

Pada siklus II, aktivitas guru meningkat sebesar $15,15 \%$. Hal ini disebabkan guru telah memperbaiki media pembelajaran dengan menggunakan LCD dan mengajak siswa keluar kelas. Menurut Miarso (1984), media yang dirancang dengan baik dapat merangsang timbulnya semacam dialog internal dalam diri siswa yang belajar sehingga dapat memicu perubahan kualitas dalam diri siswa

Padasiklus III, guru sudahmenerapkan strategi pembelajaran inkuiri terbimbing dengan maksimal sehingga aktivitas meningkat menjadi 93,94\%. Saat melaksanakan praktikum, guru sepenuhnya melakukan bimbingan karena siswa sudah mudah diatur dan bertanggung jawab terhadap tugasnya. Guru dapat mengelola kelas secara merata sehingga siswa memperoleh perhatian yang sama.

\section{B. Peningkatan Aktivitas Siswa}

Aktivitas siswa mengalami peningkatan dari siklus I sebesar $66,67 \%$ menjadi $75,76 \%$ pada siklus II dan mencapai $81,48 \%$ pada siklus III. Rendahnya aktivitas siswa pada siklus I menunjukkan bahwa respon siswa terhadap prasyarat guru masih rendah. Motivasi belajar siswa masih kurang, terlihat dari ketidaksiapan siswa terhadap pelajaran. Keaktifan siswa dalam presentasi, diskusi, dan membuat kesimpulan masih rendah dan siswa yang pandai masih mendominasi.

Pada siklus II, aktivitas siswa mengalami kemajuan, terbukti dengan bertambahnya siswayangmeresponmotivasidariguru. Siswa sudah mulai berani menjawab pertanyaan guru. Aktivitas siswa mendengarkan informasi dari guru mengalami peningkatan sebagai akibat dari penggunaan media LCD oleh guru. Namun, siswa masih malu bertanya atau takut dianggap kurang memperhatikan penjelasan guru sebelumnya.

Pada siklus III, aktivitas siswa meningkat menjadi $81,48 \%$ karena siswa sudah mampu berdiskusi baik secara berkelompok maupun dalam kelas. Siswa sudah terbiasa belajar dengan strategi pembelajaran inkuiri terbimbing. Menurut Landsberg (Maasawet, 2011:17), kerja sama ialah proses beregu di mana anggotanya saling mendukung untuk mencapai hasil melalui sumbangan pemahaman dan penguatan satu sama lain agar semuanya berpartisipasi. Hal ini lah yang terjadi selama siklus III berlangsung.

\section{Peningkatan Keterampilan Proses Siswa}

Keterampilan proses siswa mengalami peningkatan dari siklus I sebesar 55,00\%, menjadi $69,38 \%$ pada siklus II, dan mencapai 80,63\% pada siklus III. Pada siklus I, keterampilan proses siswa masih belum maksimal. Hanya dua kelompok yang masuk dalam kategori "baik", dua lainnya masih tergolong "cukup". dan masih ada satu kelompok yang tergolong "kurang". Pada siklus ini, siswa kurang jelas menerima informasi dari guru akibat rendahnya inisiatif siswa untuk bertanya.

Pada siklus II, terdapat kemajuan dalam 
keterampilan proses siswa, di mana sudah tiga kelompok tergolong "baik" dan dua kelompok tergolong "cukup", serta tidak ada kelompok yang tergolong "kurang". Berdasarkan pengamatan, pada siklus II satu kelompok masih salah membuat hipotesis, disebabkan kelompok tersebut masih kurang menyimak dan banyak bermain.

Pada siklus III, kemajuan besar terjadi pada kelompok siswa, di mana hanya satu kelompok yang tergolong "cukup", dan empat sisanya tergolong "baik". Piaget (Hughes, 2012:30) menemukan bahwa perkembangan kognitif sebagian besar bergantung pada seberapa jauh anak akan aktif berinteraksi dengan lingkungannya. Di dalam kelas, penyajian pengetahuan dengan mendorong siswa menemukan sendiri pengetahuan tersebut dilakukan melalui interaksi inkuiri terbimbing.

\section{Peningkatan Motivasi Belajar Siswa}

Motivasi belajar siswa mengalami peningkatan dari siklus I sebesar $60,74 \%$, menjadi $69,38 \%$ pada siklus II, dan mencapai $80,63 \%$ pada siklus III. Pada siklus I, motivasi belajar siswa masih rendah akan tetapi aspek mencoba berbuat lebih baik pada keseluruhan siswa cukup tinggi (88,89\%) yang mengindikasikan siswa ada keinginan untuk berusaha meningkatkan pengetahuannya. Siswa yang pandai dan bermotivasi tinggi masih belum dapat bekerja sama dengan temannya yang lain.

Pada siklus II, terdapat peningkatan motivasi belajar siswa, terutama dalam aspek penyelesaian tugas dan kemampuan berdiskusi. Namun pada pertemuan ketiga, skor rata-rata motivasi belajar siswa sempat menurun. Hal ini disebabkan siswa kesulitan memahami materi pencemaran tanah karena kurang berdampak langsung pada kehidupan sehari - hari. Menurut Ausubel (Hidayanto, 2009:119), belajar bermakna dapat terjadi bila siswa sudah mampu menghubungkan antara pengetahuan baru dengan pengetahuan yang dimilikinya. Guru harus terus berupaya melalui strategi inkuiri terbimbing agar permasalahan bahaya pencemaran tanah lebih dekat pada siswa.

Pada siklus III, rata - rata motivasi belajar siswa sudah masuk dalam kategori "tinggi". Aspek keaktifan mencari sumber belajar lain menduduki persentase $100 \%$, yang berarti siswa bersemangat untuk belajar dari sumber lain. Hal ini disebabkan pada akhir siklus III, guru mengajak siswa untuk studi lapangan di kawasan hutan mangrove Margo Mulyo Balikpapan Barat. Sesuai dengan pendapat Souders dan Prescott (Johnson, 2011:155), belajar langsung adalah belajar yang membuat pelajaran melekat dengan cara mencari dan menggabungkan informasi secara aktif dari tempat kerja, masyarakat, maupun ruang kelas, lalu menyematkan informasi tersebut dalam ingatan.

Akan tetapi, menurut catatan lapangan aspek bertanya pada guru masih harus perlu dimotivasi oleh guru. Sesuai dengan teori law of effect dari Thorndike (Sardiman, 2011:33) yang menyatakan bahwa motivasi akan bertambah apabila belajar disertai rasa senang/puas.

\section{E. Peningkatan Hasil Belajar Siswa}

Hasil belajar siswa mengalami peningkatan ketuntasan dari siklus I hanya $45,56 \%$ menjadi $58,00 \%$ pada siklus II, dan mencapai $86,67 \%$ pada siklus III. Pada siklus I ketuntasan siswa relatif rendah, hanya 15 orang di akhir siklus I yang tuntas belajarnya (meraih nilai di atas 65).

Pada siklus II, terjadi peningkatan pada setiap pertemuan, di mana pada akhir siklus terdapat 21 orang yang tuntas $(70 \%$ dari total siswa). Namun dalam catatan lapangan siklus II, terdapat penurunan nilai dari tes formatif 1 ke tes formatif 2 pada dua orang siswa, dan sekitar lima orang siswa mengalami penurunan dari tes formatif 2 ke tes akhir siklus II. Hal ini disebabkan oleh beberapa hal antara lain karena sakit dan materi pencemaran tanah pada siklus II cukup sulit 
untuk dipahami karena kurang berdampak langsung kepada siswa.

Pada siklus III, peningkatan juga dapat ditemukan pada tiap pertemuan, di mana di akhir siklus ketuntasan menjadi 90,00\% atau hanya sekitar tiga orang siswa yang masih belum tuntas. Berdasarkan catatan lapangan, ketiga siswa tersebut memiliki masalah tersendiri yang mempengaruhi prestasi belajar mereka.

Siswa pertama memiliki masalah pada kondisi fisik yang lemah akibat sakit asma sehingga sulit belajar lebih keras. Solusi yang bisa ditawarkan di antaranya pemberian tambahan pelajaran di rumah siswa tersebut dan perlunya kerja sama guru dengan orang tua agar perhatian dan motivasi untuk belajar harus terus diberikan.

Siswa kedua memiliki masalah dalam membagi waktu antara belajar dan bekerja akibat harus membantu ekonomi keluarganya. Masalah ini sekiranya dapat diatasi dengan jalan pemberian beasiswa dan memberi pemahaman pada orang tua agar memberi kelonggaran waktu pada anaknya untuk belajar

Siswa terakhir memiliki masalah psikologis karena kerapkali memperoleh intimidasi (bullying) dari orang tuanya, seperti paksaan kehendak orang tua agar anaknya menjadi juara kelas atau hukuman orang tua berupa amarah dan pukulan saat hasil rapot yang buruk. Menurut Andrew Mell (Mulyadi, 2010:122), bullying terjadi jika seseorang merasa teraniaya dan direndahkan orang lain baik secara verbal, fisik, maupun mental.
Harus ada pihak ketiga dari keluarga yang bisa menjembatani anak dan orang tuanya. Guru bisa memotivasi anak tersebut untuk selalu rajin belajar dan dapat memberi pelajaran tambahan.

\section{KESIMPULAN}

Berdasarkan analisis hasil penelitian, beberapa kesimpulan utama dapat diperoleh antara lain:

1) Penerapan strategi pembelajaran inkuiri di dalam kelas memicu terjadinya kenaikan keterampilan proses siswa dalam melakukan praktikum biologi, khususnya mengenai dampak pencemaran lingkungan. Tiap siklus, persentase keterampilan proses siswa mengalami kenaikan dari 55,00\% (siklus I) menjadi $69,38 \%$ (siklus II), dan terakhir mencapai $80,63 \%$ (siklus III).

2) Penerapan pembelajaran inkuiri terbimbingjuga berdampak pada kenaikan motivasi belajar biologi siswa. Kenaikan motivasi belajar tiap siklus diketahui dari persentase motivasi belajar siswa mulai dari $60,74 \%$ (siklus I), menjadi 73,33\% (siklus II), dan terakhir mencapai 80,00\% (siklus III).

3) Hasil belajar siswa sebagai dampak dari kenaikan keterampilan proses dan motivasi belajar siswa juga mengalami kenaikan di tiap siklus, yakni mulai dari rata-rata persen ketuntasan sebesar $63,09 \%$ (siklus I), menjadi 66,18\% (siklus II), dan terakhir mencapai 86,67\% (siklus III).

\section{DAFTAR PUSTAKA}

Arikunto, S. 2009. Penelitian Tindakan Kelas. Jakarta: Rineka Cipta

Asmani, J.M. 2009. Belajar Efektif Untuk SMP dan SMA. Yogyakarta: Diva Press

Dimyati dan Mudjiono. 2002. Belajar dan Pembelajaran. Jakarta: Rineka Cipta

Djamarah, S dan A. Zain. 2002. Strategi Belajar Mengajar. Jakarta: Rineka Cipta

Hidayanto, D.N. 2009. Pemikiran Pendidikan: Dari Filsafat ke Ruang Kelas. Jakarta: Penerbit LeKDiS 
Hughes, A.G. dan E.G. Hughes. 2012. Learning \& Teaching: Pengantar Psikologi Pembelajaran Modern. Bandung: Penerbit Nuansa

Ibrahim, M. 2007. Pembelajaran Inkuiri. [Online]. Tersedia: http://herfis.com/2009/07/pembelajaran-inkuiri.html [Januari, 2012]

Johnson, E.B. 2011. Contextual Teaching \& Learning (CTL): Menjadikan Kegiatan Belajar-Mengajar Mengasyikkan dan Bermakna. Bandung:: Penerbit Kaifa

Maasawet, E.T. 2011. Meningkatkan Kemampuan Kerjasama Belajar Biologi Melalui Penerapan Strategi Inkuiri Terbimbing Pada Siswa Kelas VII SMP Negeri VI Kota Samarinda Tahun Pelajaran 2010/2011. Jurnal Bioedukasi Volume 2, Nomor 1

Miarso, Y. 1984. Teknologi Komunikasi Pendidikan: Pengertian dan Penerapannya di Indonesia. Jakarta: Penerbit Rajawali

Mulyadi, H. 2010. Diagnosis Kesulitan Belajar. Yogyakarta: Penerbit Nuha Litera

Nuryani. 2005. Strategi Belajar Mengajar Biologi. Malang: UM Press.

Purwanto. 2010. Evaluasi Hasil Belajar. Yogyakarta: Pustaka Pelajar

Rustaman, N. et. al.,. 2003. Strategi Belajar Mengajar Biologi. Bandung: FPMIPA-UPI.

Sardiman. 2011. Interaksi dan Motivasi Belajar-Mengajar. Jakarta: Penerbit PT RajaGrafindo Persada

Semiawan, C.R. 1992. Pendekatan Ketrampilan Proses: Bagaimana Mengaktifkan Siswa dalam Belajar. Jakarta: Penerbit Grasindo

Slameto. 2010. Belajar dan Faktor-faktor yang Mempengaruhinya. Jakarta: Rineka Cipta.

Sudjana, Nana. 1990. Dasar - Dasar Proses Belajar Mengajar. Bandung: Sinar Baru Algesindo.

Sumiati dan Asra. 2008. Metode Pembelajaran. Bandung: CV Wacana Prima.

Susanto, P. 2003. Keterampilan Dasar Mengajar IPA berbasis Konstruktivisme. Malang: JICA.

Usman, Uzer. 2010. Menjadi Guru Profesional. Bandung: Penerbit Remaja Rosda Karya

Widyaningtyas. 2010. Educare: Jurnal Pendidikan dan Budaya. [Online]. Tersedia: http://educare.e-fkipunla.net/ index2.php?option=com_content\&do_pdf=1\&id=49 [Januari, 2012] 